\title{
Novel regulation of the homeotic gene Scr associated with a crustacean leg-to-maxilliped appendage transformation.
}

\section{Citation}

Abzhanov, A., and TC Kaufman. 1999. "Novel regulation of the homeotic gene Scr associated with a crustacean leg-to-maxilliped appendage transformation." Development 126 160: 1121-1128.

\section{Permanent link}

http://nrs.harvard.edu/urn-3:HUL.InstRepos:12490415

\section{Terms of Use}

This article was downloaded from Harvard University's DASH repository, and is made available under the terms and conditions applicable to Other Posted Material, as set forth at http:// nrs.harvard.edu/urn-3:HUL.InstRepos:dash.current.terms-of-use\#LAA

\section{Share Your Story}

The Harvard community has made this article openly available.

Please share how this access benefits you. Submit a story.

\section{Accessibility}




\title{
Novel regulation of the homeotic gene Scr associated with a crustacean leg-
}

\section{to-maxilliped appendage transformation}

\author{
Arhat Abzhanov and Thomas C. Kaufman* \\ Howard Hughes Medical Institute, Department of Biology, Indiana University, Bloomington, IN 47405, USA \\ *Author for correspondence (E-mail: kaufman@bio.indiana.edu) \\ Accepted 8 January; published on WWW 15 February 1999
}

\section{SUMMARY}

Homeotic genes are known to be involved in patterning morphological structures along the antero-posterior axis of insects and vertebrates. Because of their important roles in development, changes in the function and expression patterns of homeotic genes may have played a major role in the evolution of different body plans. For example, it has been proposed that during the evolution of several crustacean lineages, changes in the expression patterns of the homeotic genes Ultrabithorax and abdominal- $A$ have played a role in transformation of the anterior thoracic appendages into mouthparts termed maxillipeds. This homeotic-like transformation is recapitulated at the late stages of the direct embryonic development of the crustacean Porcellio scaber (Oniscidea, Isopoda). Interestingly, this morphological change is associated with apparent novelties both in the transcriptional and post- transcriptional regulation of the Porcellio scaber ortholog of the Drosophila homeotic gene, Sex combs reduced (Scr). Specifically, we find that $\mathrm{Scr}$ mRNA is present in the second maxillary segment and the first pair of thoracic legs (T1) in early embryos, whereas protein accumulates only in the second maxillae. In later stages, however, high levels of SCR appear in the T1 legs, which correlates temporally with the transformation of these appendages into maxillipeds. Our observations provide further insight into the process of the homeotic leg-to-maxilliped transformation in the evolution of crustaceans and suggest a novel regulatory mechanism for this process in this group of arthropods.

Key words: Homeotic gene, Sex combs reduced, Porcellio scaber, Isopoda, Crustacean, Maxilliped, Evolution

\section{INTRODUCTION}

Homeotic (HOM-C/Hox) genes are known to specify the identity of segments along the antero-posterior axis in insects. Genetic studies on Drosophila melanogaster and other insects have demonstrated that the products of the Hox genes control the transcription of numerous downstream genes within their expression domains (Carroll, 1995; Graba et al., 1997). Comparative studies of various insect orders reveal that the expression domains of $\mathrm{HOM}-\mathrm{C} / \mathrm{Hox}$ genes are relatively invariant within the Class Insecta, which is consistent with a highly conserved basic body plan (Beeman et al., 1993; Friedrich and Tautz, 1995; Warren and Carroll, 1995; Rogers and Kaufman, 1997). Specifically, the genes labial (lab), proboscipedia $(p b)$, Deformed $(D f d)$ and Sex combs reduced ( $\mathrm{Ccr}$ ) have been shown to specify the segments of the head in Drosophila (Kaufman et al., 1990) and are likely to perform a similar function in other insects (Rogers and Kaufman, 1997; Peterson et al., 1998). The extension of these studies into Crustacea, a close sister group of insects (Ballard et al., 1992; Boore et al., 1995; reviewed in Gilbert and Raunio, 1997; Boore et al., 1998), has proved to be very useful in understanding the evolution of Hox genes themselves and their role in arthropod evolution (Averof and Akam, 1995). A recent study by Averof and Patel (1997) presented evidence for a role of the 'trunk' genes $U b x$ and $a b d-A$ in a homeotic-like transformation of the anterior thoracic legs into maxillipeds independently in several crustacean lineages. In particular, the absence of UBX and ABD-A from anterior segments of certain derived malacostracan crustaceans correlates with the appearance of maxillipeds on those segments in adults (Averof and Patel, 1997). However, a better understanding of this process requires further knowledge of homeotic gene expression patterns, especially of the 'head' genes whose role in such a process can be expected. In this study we have focused on the expression pattern of $S \mathrm{cr}$ as it is an important homeotic gene defining the posterior boundary of the insect head (Kaufman et al., 1990; Zeng et al., 1993). After studying the distribution patterns of Scr mRNA and protein in $P$. scaber embryos, we found that the appearance and accumulation of these products correlates well with the transformation of the first thoracic pair of limbs into mouthpart maxillipeds. We also conclude that $\mathrm{Scr}$ is post-transcriptionally regulated during the process. We suggest that $S c r$ is involved in this homeotic-like transformation, both in the ontogeny and phylogeny of the isopod malacostracans and likely other crustaceans as well. Further, a comparison of the expression pattern and function of $\mathrm{Scr}$ between insects and crustaceans reveals likely and interesting evolutionary changes in the role of this gene in these two groups. 


\section{MATERIALS AND METHODS}

\section{$P$. scaber cultures and embryo collection}

Colonies of the common woodlouse Porcellio scaber (Isopoda, Oniscidae) were originally established from animals collected around Bloomington, IN, USA. Breeding colonies of about 1000 animals were maintained in large plastic boxes at $22^{\circ} \mathrm{C}$ with a constant light source. Females of Porcellio scaber brood about 50 embryos in a marsupium formed by large oostegite plates of the walking legs on the ventral side of the thorax. The transparency of the oostegite plates allows determination of the developmental stage of the embryos. The developmental stages based on the appearance and change of the external morphological features are described by Whitington et al. (1993). Embryogenesis in Porcellio scaber lasts about 3 weeks, with manca larvae remaining in the marsupium for several days after hatching. We estimate that it takes embryos about 3 days to develop from the $45-50 \%$ stage to the $75-80 \%$ stage at $22^{\circ} \mathrm{C}$. The embryos were dissected from the marsupium using a pair of dissecting needles and washed in $0.01 \mathrm{M}$ phosphate-buffered saline (PBS) before fixation for in situ hybridization and antibody staining.

\section{Cloning partial cDNAs of Sex combs reduced}

Total mRNA was isolated from about 50 embryos with TRIzol®Reagent (Life Technologies) following the RNA isolation protocol provided by the manufacturer. RT-PCR and detailed cDNA cloning procedures have been described previously (Rogers et al., 1997). Based on a PCR survey with degenerate homeobox primers used on both cDNA and genomic woodlouse DNA, we have concluded that only a single $\mathrm{Scr}$ homolog (ortholog) is present in Porcellio scaber (A. A. and T. C. K., unpublished). The degenerate primers used to clone a partial Scr cDNA containing the homeobox and the upstream variable region were designed from the conserved regions PQIYPWM and WFQNRR, as previously described (Rogers et al., 1997). cDNA clones were sequenced using the ABI PRIZM ${ }^{\mathrm{TM}}$ Dye Terminator Cycle Sequencing Ready Reaction Kit (Perkin Elmer). The accession number for the Porcellio scaber Scr sequence in GenBank is AF101431.

\section{Sequence analysis}

The cDNA sequences obtained were compared with the NCBI sequence database using BLAST and with unpublished sequences of cDNAs from various arthropods cloned in this laboratory. All sequences were analysed using MacVector ${ }^{\mathrm{TM}}$ 6.0.1 (Kodak) software.

\section{Fixation of embryos, in situ hybridization and antibody staining}

Distribution of Scr mRNA was analysed using the in situ hybridization protocol described by Panganiban et al. (1994) with modifications from Rogers et al. (1997), except that protease incubation was decreased from 1 hour to 10-12 minutes. The monoclonal antibody against DLL was described by Panganiban et al. (1994); the monoclonal antibody, MAb 4D9 against EN was described in Patel et al. (1989a); the monoclonal antibody FP6.87 against UBX and ABD-A is described by Kelsh et al. (1994); and the polyclonal rat antibody against amino acids 240-417 of Drosophila SCR (containing the YPWM-motif, the homeobox and the C terminus) was a kind gift from D. J. Andrew, Johns Hopkins University School of Medicine. The immunochemical staining procedure is described by Kelsh et al. (1994) and Averof and Patel (1997).

\section{Microscopy and photography}

All mounting, photographing and scanning electron micrograph procedures have been described previously (Gorman and Kaufman, 1995; Rogers et al., 1997).

\section{RESULTS}

\section{Early development of the Porcellio scaber embryo}

Porcellio scaber, the common woodlouse (order Isopoda), is a
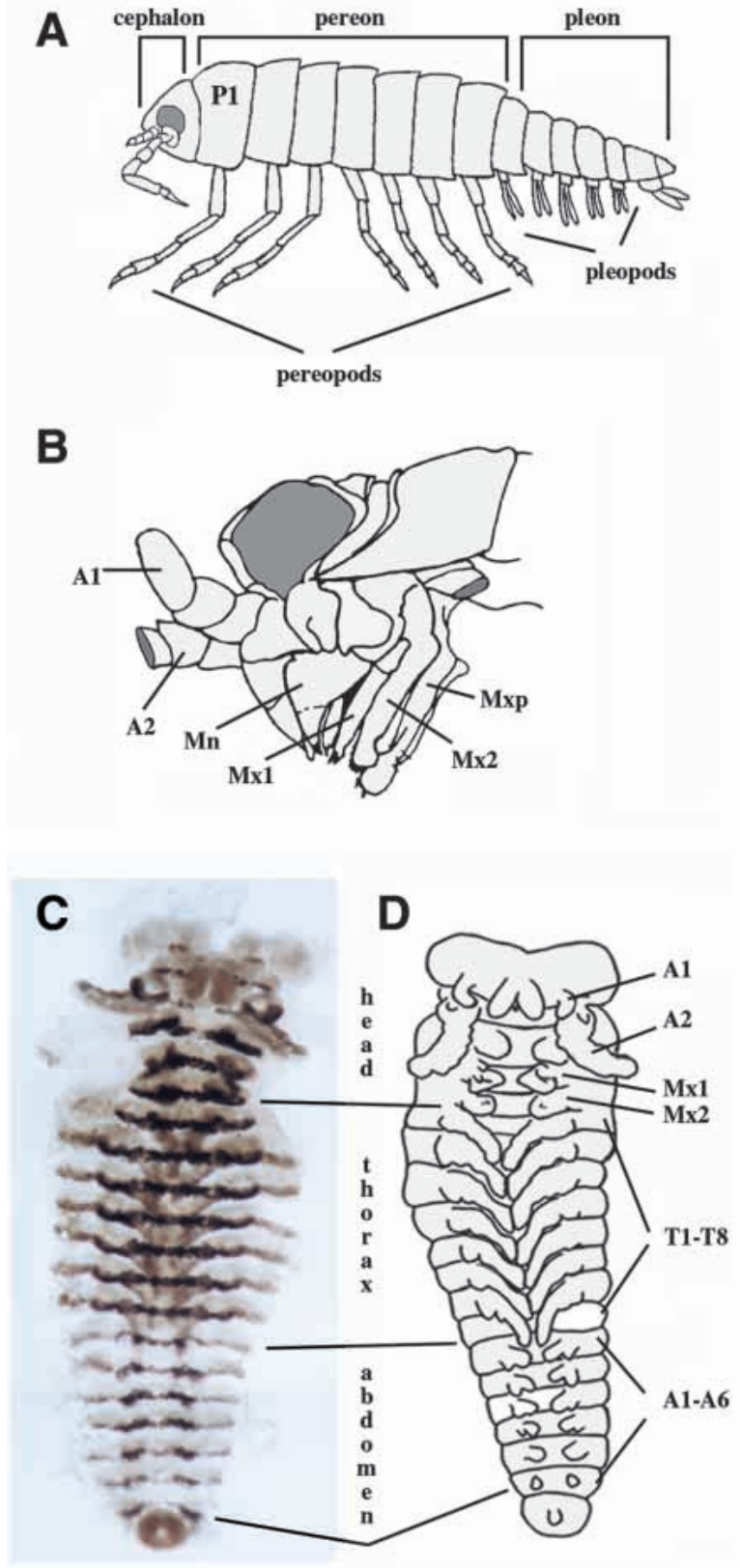

Fig. 1. The isopod body plan and development. (A) Schematic representation of isopod external morphology. Three tagma can be distinguished in the adult isopod: cephalon (mandibulate head plus T1 segment with maxillipeds), pereon with seven segments, and pleon with six segments. Pereopods are uniramous walking legs in adult isopods. Pleopods are small biramous appendages used for respiration. P1 is the first adult pereonic segment. (B) Schematic lateral representation of the isopod cephalon (after Manton, 1977). Labels indicate appendages rather than segments. The cartoon shows the first antennae (A1), the second antennae (A2), mandibles (Mn), the first maxillae (Mx1), the second maxillae (Mx2) and maxillipeds (Mxp). (C,D) Porcellio scaber embryo stained with antibody recognising EN to reveal the segments and the outline of the embryo. There are 20 visible EN stripes corresponding to the six head segments labelled as in B, eight embryonic thoracic segments (T1T8) and six abdominal segments (A1-A6). Note that the thorax of the embryo does not directly correspond to the pereon of the adult isopod. Additionally, the adult cephalon is derived from the embryonic head and the anterior thoracic T1/Mxp segment. 
representative of the superorder Peracarida, subclass Malacostraca, the largest group of living crustaceans. The development of Porcellio scaber is direct (epimorphic) and results in the hatching of a larva that possesses all the morphological features of the adult isopod except that it lacks a seventh pair of thoracic (pereonic) appendages (Kaestner, 1970; Beklemishev, 1964). The archetypal adult malacostracan has three tagma: the mandibulate head of six segments, the 'thorax' (pereon) with eight pairs of uniramous legs and the 'abdomen' (pleon) with five pairs of appendages used for locomotion and/or breathing and one pair of terminal appendages called uropods (See Fig. 1A). In the lineage leading to the isopods, the first pair of thoracic limbs have apparently been transformed into maxillipeds (Schram, 1986). In adult isopods these appendages often have flat proximal articles (basipodites) that posteriorly and ventrally enclose the mandibles and the two pairs of maxillae and serve a function analogous to that of the insect labium (Brusca and Brusca, 1990; a schematic isopod head is shown in Fig. 1B).

To better understand the leg-to-maxilliped transformation, we examined scanning electron micrographs (SEM) taken at different developmental stages. The tagma boundaries are established very shortly after germband elongation with the three tagma clearly discernible (shown in Fig. 1C). Initially, the thorax consists of eight post-gnathal segments with the first pair of thoracic appendages developing as large uniramous legs reminiscent of the above mentioned ancestral state (Fig. 1D). The latter continue to develop as legs until the $60-70 \%$ developmental stage (stages are as in Whitington et al., 1993). At about the 75\% stage, a series of morphological changes results in a transformation of the $\mathrm{T} 1$ legs into maxillipeds (Mxp) and fusion of the T1/Mxp segment with the head capsule (see electron micrographs in Fig. 2A-C). As a result the tagma that begins as the embryonic thorax (T1T8 with the T8 segment initially lacking appendages) subsequently transforms to the posterior adult head (T1/Mxp) and the adult pereon (P1-P7, all bearing uniramous walking legs). Therefore, the originally established tagma boundary between the second maxilla and the first thoracic segment is shifted posteriorly behind the T1/Mxp and anterior to the first pereonic segment (T2/P1). This ontogenic shift mirrors the phylogenetic change that is thought to have occurred in the evolution of this group of isopods. As late development progresses, the maxillipeds grow a long, spoonlike exopod and a short 3-jointed branch, the endopod, next to the endite on the tip of the large flat basipodites. The appendages on the more posterior thoracic or pereonic segments
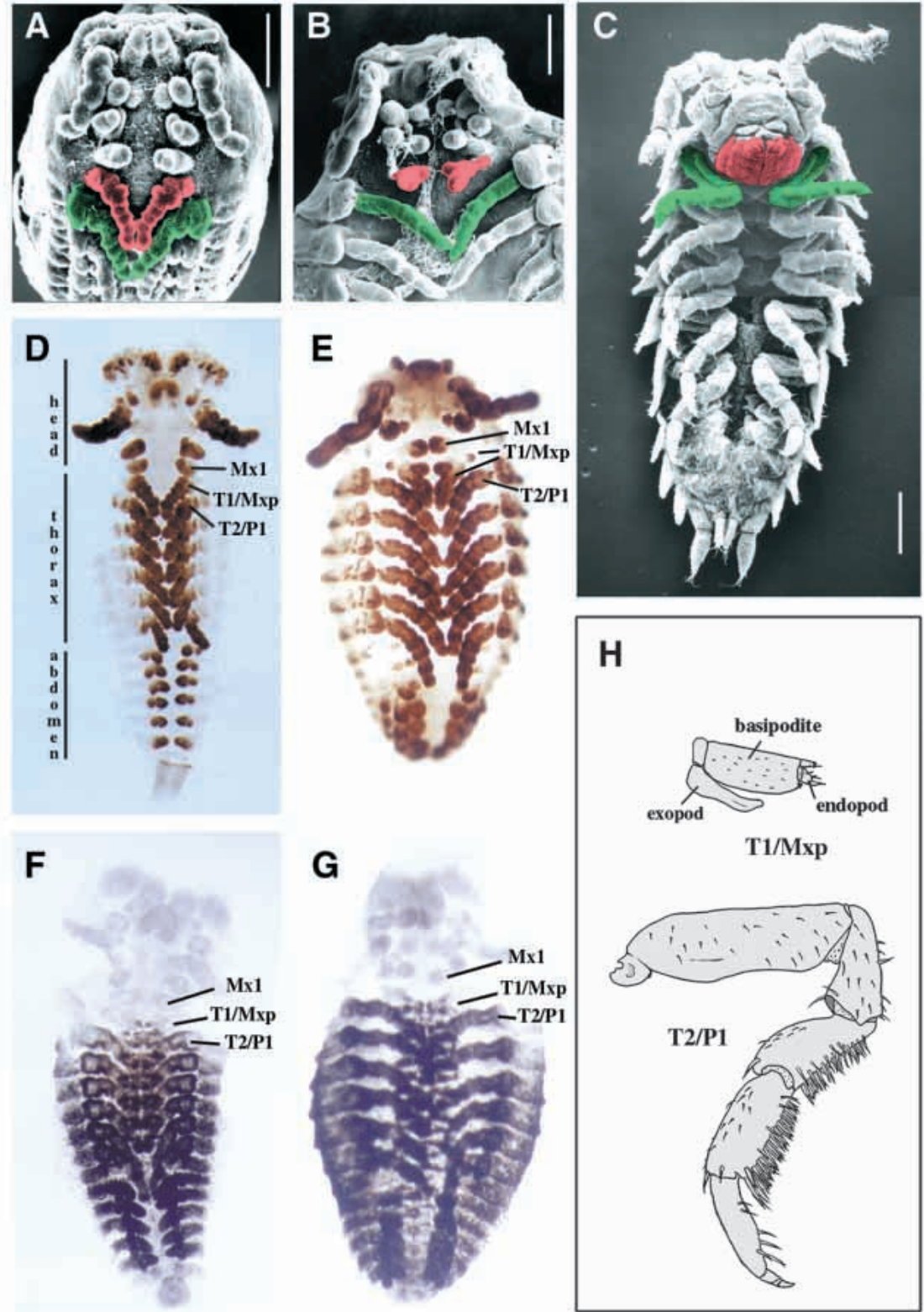

G
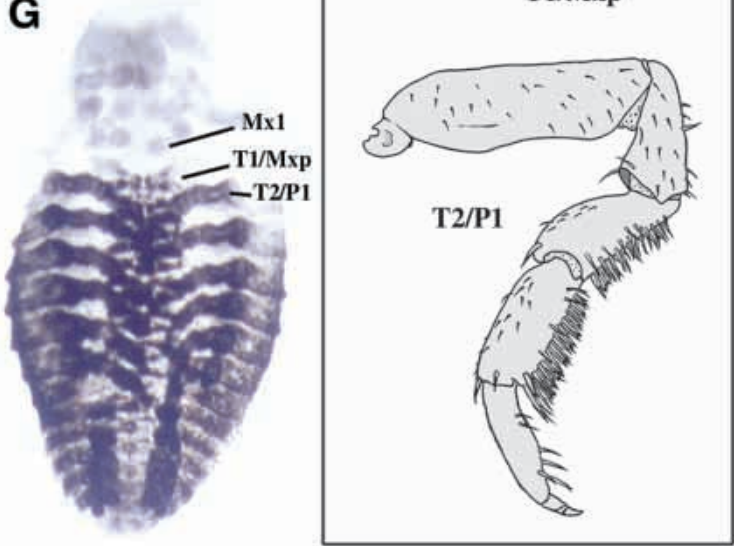

Fig. 2. Development of maxillipeds from leg-like appendages. (A-C) Scanning electron micrographs of the $45-50 \%$ stage (middle), $75-80 \%$ stage (late) and manca larva developmental stages, respectively. The maxillipeds are false-coloured in red and the second thoracic appendages/ first pereopods are false-coloured in green. The first thoracic limbs (A) can be seen in their transformation to maxillipeds (B,C). (D,E) 25-30\% and 75$80 \%$ stage embryos stained with a polyclonal antibody (brown) to DLL. The development of the second maxillary appendage, maxilliped and first pereopod (P1) is revealed. Embryonic head, thorax and abdomen are indicated. (F,G) Staining with antibody FP6.87 (black) recognizing UBX and ABD-A in 45-50\% and 75-80\% stage embryos. UBX and ABD-A are expressed in the developing trunk (thorax and abdomen) of the embryo with the anterior boundary in the posterior ventral part of the T1/Mxp segment in accordance with previous observations (Averof and Patel, 1997). Mxp appendages do not express $U b x-a b d A$. (H) A diagram representing the adult morphology of T1/Mxp and T2/P1 appendages. The Mxp develops an outer narrow, spoon-like branch (exopod) and a small 3-jointed endopod on the tip of large flat basipodite after about the $75 \%$ stage. Bars, $100 \mu \mathrm{m}$ (A-C). In D-G the labels indicate appendages rather than segments. 


\section{Segmental expression of EN}

The boundaries for the expression domains of the $S c r, U b x$ and $a b d-A$ products were defined using the pattern of Engrailed (EN) as revealed by the monoclonal antibody mAb 4D9 (Patel et al., 1989a). This antibody recognizes a conserved epitope in EN and INV. Partial cDNAs of two engrailed-class genes have been cloned from $P$. scaber, both of them contain the epitope and are expressed in coinciding patterns (A. A. and T. C. K., unpublished). The EN expression pattern is similar to that observed in insects and other crustaceans at the segmented germ band and later stages (Patel et al., 1989a,b; Rogers and Kaufman, 1996). EN is accumulated in the posterior portion of each developing segment. The stripes of EN are observed at the earliest recognisable germ band stage and appear sequentially as posterior segments are added during development (a more detailed study will be published elsewhere).

There are six EN-accumulating segments in the head: two preoral and four postoral corresponding to the ocular, first antennal (A1), second antennal (A2), mandibular (Mn), first maxillary (Mx1) and second maxillary (Mx2) segments (Fig. 1C). As shown in Fig. 1C, the ocular, A1 and A2 stripes are relatively narrow (1-2 cells) except in the posterior part of the A2 appendage. In contrast, the Mn, Mx1 and Mx2 stripes are at least $4-5$ cells wide. Later in development the EN-expressing dorsal part of the Mn segment and some of the A2 segment's dorsalmost material form a 'dorsal ridge' for the more anterior segments. The posterior part of this structure, together with a similar 'dorsal ridge' formed by the dorsal T2/P1 segment, will enclose both the maxillary and the T1/Mxp segments (not shown). Note that there is no lateral/dorsal expression of EN in the T1/ Mxp segment (Fig. 1C), which serves to distinguish it from the more posterior thoracic/pereonic segments. Each of the eight thoracic segments and all pereopods accumulate EN in their posterior portion. The T8/P7 stripe remains relatively thin (2-3 cells wide) after the $45 \%$ stage as the growth of the T8/P7 segment is not comparable to the other more anterior $\mathrm{T} / \mathrm{P}$ segments. Additionally, T8/P7 does not develop appendages until after hatching. Throughout most of embryonic development, the width and size of the T8/P7 EN stripe resembles that of the more posterior abdominal segments. EN is expressed in each of the six appendagebearing abdominal segments and appendages.

\section{Distalless (DLL) as an indicator of limb morphology}

The polyclonal antiserum against Distalless (DLL), which we used for this study, is known to specifically recognise DLL in a wide range of taxa (Panganiban, 1998). In conjunction with the SEM analysis it serves as an important indicator of appendage morphology (Fig. 2D,E). Distribution of DLL in the head of $P$. scaber reveals a horseshoe-shaped labrum, a pair of small first antennae (antenullae), large uniramous second antennae, branched Mx1 and uniramous Mx2 appendages. There is no accumulation of DLL in the mandibular ectoderm. Fig. 2D demonstrates that until the 50-60\% developmental stage the T1/Mxp pair of appendages develop indistinguishably from the T2/P1-T7/P6 legs. However, both the SEM observations (Fig. 2B) and DLL expression (Fig. 2E) clearly show the transformation of the initially leg-like $\mathrm{T} 1$ appendages into maxillipeds at the $60-75 \%$ stages. In particular, DLL is expressed in and is probably involved in development of the maxilliped branches (exopods and endopods). In contrast, it is apparent from the same figures that the T2/P1 through T7/P6 appendages continue to develop as uniramous walking legs. Interestingly, although no appendages develop on the T8/P7 segment before the end of embryogenesis, DLL is weakly expressed in a few cells that form a small island in the posterior part of the T8/P7 segment (Fig. 2E; A.A. and T.C.K., unpublished). This suggests that the arrest of formation and growth of the T8/P7 legs (the last pair of pereonic walking legs) is downstream of DLL function. There are six biramous appendages in the abdomen - five pairs of pleopods and a single pair of uropods. The A1 pair of appendages appears to develop somewhat more slowly than the rest of the abdominal appendages (not shown). At the late developmental stages DLL expression is also established in a number of small outgrowths on the head and trunk of the embryo (Fig. 2E).

\section{Trunk expression of $U b x$ and $a b d-A$}

In agreement with previous studies by Averof and Patel (1997) on other crustacean species and as shown in Fig. 2F,G, Ultrabithorax (UBX) and Abdominal-A (ABD-A) are not
Fig. 3. Alignment of the deduced amino-acid sequences for $\mathrm{Scr}$ homologs from Drosophila melanogaster (DM), the milkweed bug Oncopeltus fasciatus (OF), the cricket Acheta domestica (AD), the firebrat Thermobia domestica (TD), the woodlouse Porcellio scaber (PS) and the brine shrimp Artemia

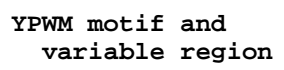

PQIYPWMKRVHLGT STVNANG PQIYPWM------QQRR-----POIYPWMK-----Q -------PQIYPWMK-----Q ------PQIYPWMK-----QR----S-A-----

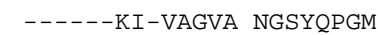
----KI-VAGAGAVAHFOPGM PL----RSQFGKCQ

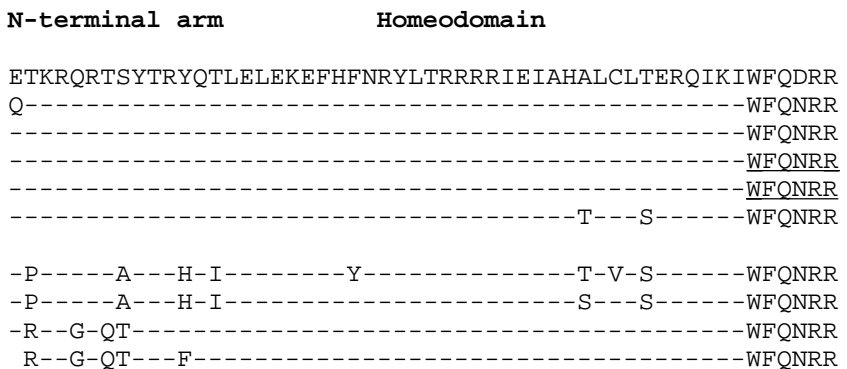

franciscana (AF). For comparison, amino acid sequences of homologs of Dfd and Antp from Drosophila and Artemia are included in the alignment. Underlined sequences indicate the amino acid sequences used for designing degenerate PCR primers for cloning. Dashes mark the amino acids identical with Drosophila Scr. The YPWM motif is a highly conserved protein-protein interaction domain located upstream of the homeodomain in all HOM-C/Hox genes. Note that the gene-specific variable region that is important in determination of homology is located between the YPWM motif and the N-terminal arm of the homeobox. The N-terminal arm of the homeobox and the homeodomain itself are vital in HOM-C/Hox functional gene specificity and are also very conserved (Zeng et al., 1993). As the alignment shows, the PS sequence is identical to the insect Scr sequences over the N-terminal arm and homeodomain sequences. In the variable region, the PS sequence is most similar to the AD and TD Scr sequences. In comparison, the sequences of $D f d$ and Antp have a different set of gene-specific amino acids in the aligned regions. The sequence of the AF $D f d$ variable region was not previously cloned and will be described elsewhere. 
detected in the maxillipeds at any point in development. The antibody does, however, recognise the proteins in a majority of the more posterior limb-bearing segments of the pereon and pleon. The fact that the early development of the limbs on the T1/Mxp and the pereonic segments is indistinguishable suggests that UBX and ABD-A do not play an instructive role in early thoracic leg morphogenesis.

\section{The Scr ortholog of Porcellio scaber}

To further understand crustacean body plan evolution and the leg-to-maxilliped transformation, we studied the mRNA expression patterns of the 'head' Hox genes in Porcellio scaber using in situ hybridization. RNA probes were generated from partial cDNAs cloned from embryos via RT-PCR. Cloned cDNA fragments were compared to the known amino acid sequences of $\mathrm{Scr}$ and other HOM-C genes from various insects and the brine shrimp Artemia franciscana. Fig. 3 shows the alignment of the Scr homologs from Drosophila melanogaster (Diptera, Insecta), the milkweed-bug Oncopeltus fasciatus (Hemiptera, Insecta), the cricket Acheta domestica (Orthoptera, Insecta), the firebrat Thermobia domestica (Thysanura, Insecta), the woodlouse Porcellio scaber (Isopoda, Crustacea), and the brine shrimp Artemia franciscana (Anostraca, Crustacea) (sequences are derived from Averof and Akam, 1995; Rogers at al., 1997; this work). On the basis of the encoded amino acids of the homeobox and the variable regions located downstream of the YPWM motif (Rogers et al., 1997) that are shared with $\mathrm{Scr}$ sequences of related organisms, the alignment demonstrates that the Porcellio scaber partial cDNA sequence presented most closely resembles Scr and not other HOM-C genes (Fig. 3).

\section{Scr mRNA and protein in $45-50 \%$ stage embryos display distinct patterns of accumulation}

A partial cDNA of a single $S c r$ homolog from Porcellio scaber and an antibody that detects SCR were used to study the $\mathrm{Scr}$ mRNA and protein expression patterns in young (45-50\% stage) and older (75-80\% stage) embryos of Porcellio scaber, Isopoda. The resulting expression patterns were compared with previously published results from Drosophila melanogaster (Diptera) and other insects (Carroll et al., 1988; Pattatuci and Kaufman, 1991; Gorman and Kaufman, 1995; Rogers et al., 1997; Peterson et al., 1998).

At early stages of development the embryo of Porcellio scaber has T1/Mxp appendages identical to the rest of the thoracic legs and different from the mouthparts (Fig. 2A,D). We found that beginning early in development $S c r$ mRNA is accumulated in the Mx2 segment and appendages (Fig. 4A,B). Expression is also observed in the posterior Mx1 segment and the T1/Mxp appendages and more weakly in the outer branches of the first pair of maxillae (Mx1). Cells of the ventral posteriormost part of the $\mathrm{Mx} 2$ segment do not accumulate detectable levels of $\mathrm{Scr}$ transcript, implying that expression may be parasegmental in this portion of the ectoderm. It is more difficult to determine the anterior boundary of the $\mathrm{Scr}$ expression domain because $S c r$ expression, if any, is very weak in the Mx1 segment. The strong expression of Scr mRNA in the T1/Mxp appendages is not uniform and is restricted principally to the distal half (Fig. 4B).

The distribution of SCR was determined using a polyclonal antibody (kindly provided by D. J. Andrew) raised against the homeobox-containing $\mathrm{C}$ terminus of Drosophila SCR. This antibody can specifically detect nuclear-localized SCR in Drosophila embryos (Fig. 4F) and other arthropods (unpublished). In $P$. scaber early embryos this antibody revealed SCR only in the nuclei of cells of the second maxillary appendages (Fig. 4C-E), which constitute only a subset of those cells where $S c r$ mRNA is detected. The leg-like T1/Mxp and T2/P1-T7/P6 thoracic appendages at this stage do not accumulate SCR at detectable levels. The Mx1 appendages and the Mx2 ventral ectoderm also appear to be devoid of SCR. It cannot be ruled out that SCR is present in these appendages at very low levels and is not detected by the polyclonal SCR antibody. However, no such drastic difference is observed in Scr mRNA distribution.

\section{Scr mRNA and protein distribution in the $75-80 \%$ stage shows identical patterns in the head and maxilliped appendages}

The discrepancy between mRNA and protein accumulation persists until about the 50-75\% developmental stage. At around the $50-75 \%$ stages the T1/Mxp appendages follow a different developmental path from the rest of the thoracic/pereonic appendages and transform into maxilliped mouthparts (Fig. 2B,E). In situ hybridization reveals that $S c r$ mRNA is expressed in a pattern similar to that in the earlier stages. This includes the outer branches of the first maxillae and all of the uniramous second maxillae, the Mx2 segment ventral ectoderm and the distal portions of the T1 limbs/maxillipeds (Fig. 5A-C). During these late stages of development very high levels of SCR protein are detected throughout the Mx2 segment including the limbs and, importantly, in the distal part of the maxillipeds (Fig. $5 \mathrm{D}, \mathrm{E}, \mathrm{H})$. The domain of SCR distribution also expands into the outer branches of the Mx1 appendages and, at a somewhat lower level, parasegmentally into the posterior part of the Mx1 segment ventral ectoderm (Fig. 5F,G). High levels of both $\mathrm{Scr}$ mRNA and protein product are seen in the distal part of the large basipodite, expanding into the endopod and at lower levels in the small endite of the maxilliped (Fig. 5B,C,G; expression in the endite is not shown).

\section{DISCUSSION}

\section{Differences and similarities in the Scr mRNA expression patterns in crustacean Porcellio scaber and insects}

The monophyly and close phylogenetic relationship between members of Mandibulata (classes Myriapoda, Crustacea and Insecta) is strongly supported by both morphological and molecular data (Friedrich and Tautz, 1995; Osorio et al., 1995; reviewed in Gilbert and Raunio, 1997). This allows for the relatively accurate determination of homology amongst segments, particularly in the head. For example, the expression of EN reveals that both the insect and crustacean head consist of the most anterior ocular segment and five appendage-bearing segments: two preoral (first and second antennal in crustaceans; antennal and intercalary in insects) and three postoral segments with mouthparts (mandibular, first maxillary (maxillary in insects) and second maxillary (labial in insects); Manzanares et al., 1993; Rogers and Kaufman, 1996; reviewed in Popadic et al., 1998).

This work benefits greatly from the genetic and biochemical comparative studies on many developmental genes in Drosophila 


\section{5-50\% stage}

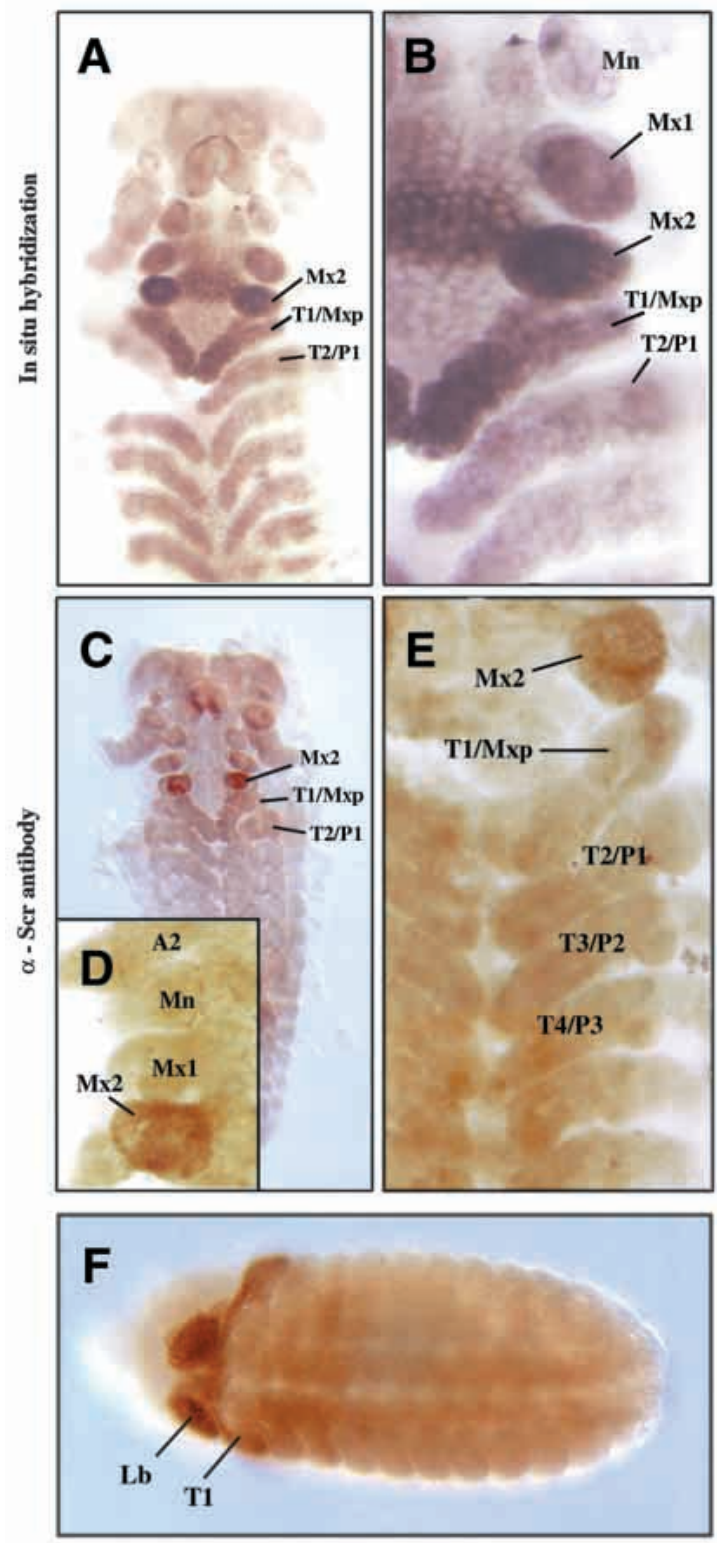

Fig. 4. Different patterns in localization of $S c r$ mRNA and protein in 45-50\% stage embryos. All labels as in Fig. 1. (A) In situ hybridization with DIG-labeled RNA probe for $\mathrm{Scr}$ reveals strong expression in the Mx2 segment and appendages as well as the Mx1 and Mxp limbs. (B) Higher magnification view of the embryo from A. (C) Distribution of SCR as detected with polyclonal rat SCR antibody. SCR can be seen in the nuclei of the second maxillary appendages only. The spot in the anterior part of the head is non-specific staining and is not nuclear. (D) Magnification of the anterior part of the head. No expression is seen in the second antennal segment (A2), mandible, Mx1 limb and Mx2 ventral ectoderm. (E) Magnification of the posterior head and thorax. There is no staining above background in the pereopod limbs. (F) SCR distribution in a Drosophila embryo as detected with this antibody. Lb, labial segment (corresponds to Mx2 in crustaceans according to Brusca and Brusca, 1990 and others); T1, the first thoracic segment.

melanogaster and other insects (McGinnis and Krumlauf, 1992; Carroll, 1994, 1995; Lawrence and Morata, 1994; Graba et al., 1997). For example, studies of the insect orders Thysanura, Hemiptera, Orthoptera and Diptera have revealed similar patterns of $S c r$ expression in all four groups (Rogers et al., 1997). It was inferred that the last common ancestor of these insects expressed Scr in the posterior lacinia (a branch of the maxilla), all of the labial segment including appendages, and in the dorsal part of the prothoracic (T1) segment (Rogers et al., 1997; Rogers and Kaufman, 1997). The expression of $\mathrm{Scr}$ in the insect labial segment parallels the second maxillary expression in Porcellio scaber and is consistent with the conclusion that these two segments are homologous. Expression in the lacinia of insects (derived from the posterior maxillary segment) may correspond to the $\mathrm{Scr}$ expression in the outer branch of the crustacean first maxillary segment. However, it is not clear at this point if these maxillary branches are themselves homologous. We suggest that both first maxillary and labial (second maxillary) domains represent the Scr expression pattern in the last common ancestor of insects and the isopod crustacean Porcellio scaber. The first thoracic expression pattern observed in the insect lineage is rather more variable than that seen in labial segment and we have concluded previously that expression in this segment, especially in the limbs, is a derived character (Rogers et al., 1997; Rogers and Kaufman, 1997). This would also suggests that the T1/Mxp expression of Scr in Porcellio scaber is derived and may be directly associated with the evolution of $\mathrm{T} 1$ appendages into maxillipeds in isopods. It is possible that T1/Mxp expression of $S c r$ is related to the retraction of $U b x$ and $a b d-A$ from that segment and that Scr transcription is normally negatively regulated by $U b x$ and/or $a b d-A$ in the rest of the thorax. We should note that this transformation is reminiscent of homeotic mutations in Drosophila associated with the ectopic expression of the anterior genes in segments posterior to their normal expression domains (Zeng et al., 1993). If correct, this recruitment of thoracic appendages to mouthparts provides the first example of a true homeotic-like morphological transformation of this kind occurring during the evolution of animals. To test this hypothesis it will be necessary to sample other crustacean orders, particularly primitive Malacostraca such as the order Leptostraca, superorder Phyllocarida, which do not develop maxillipeds but only thoracic legs, and more derived malacostracan orders that evolved more than one pair of maxillipeds (Schram, 1986).

\section{Post-transcriptional control of Scr in Porcellio scaber embryonic development}

Comparative studies of the expression patterns of Hox genes in arthropods have led to the conclusion that morphological evolution is largely generated by regulatory changes in these genes (Carroll, 1994; Warren et al., 1994). The mechanism is often shown to take place at the level of transcriptional regulation, primarily via changes in cis-regulatory elements (Cavener, 1992; Li and Noll, 1994; Arnone and Davidson, 1997). Because of their crucial role in early development, changes in the function and expression pattern of Hox genes could result in significant morphological differences between classes or even orders of organisms (Gellon and McGinnis, 1998; McGinnis and Krumlauf, 1992). We found that the accumulation patterns of $S c r$ mRNA and protein are quite dissimilar in the early development of the crustacean Porcellio scaber and that appearance of SCR in the T1/Mxp appendages correlates both in time and space with a transformation of these limbs into mouthparts. Crustacean development often includes multiple morphologically distinct larval stages which require 
$75-80 \%$ stage
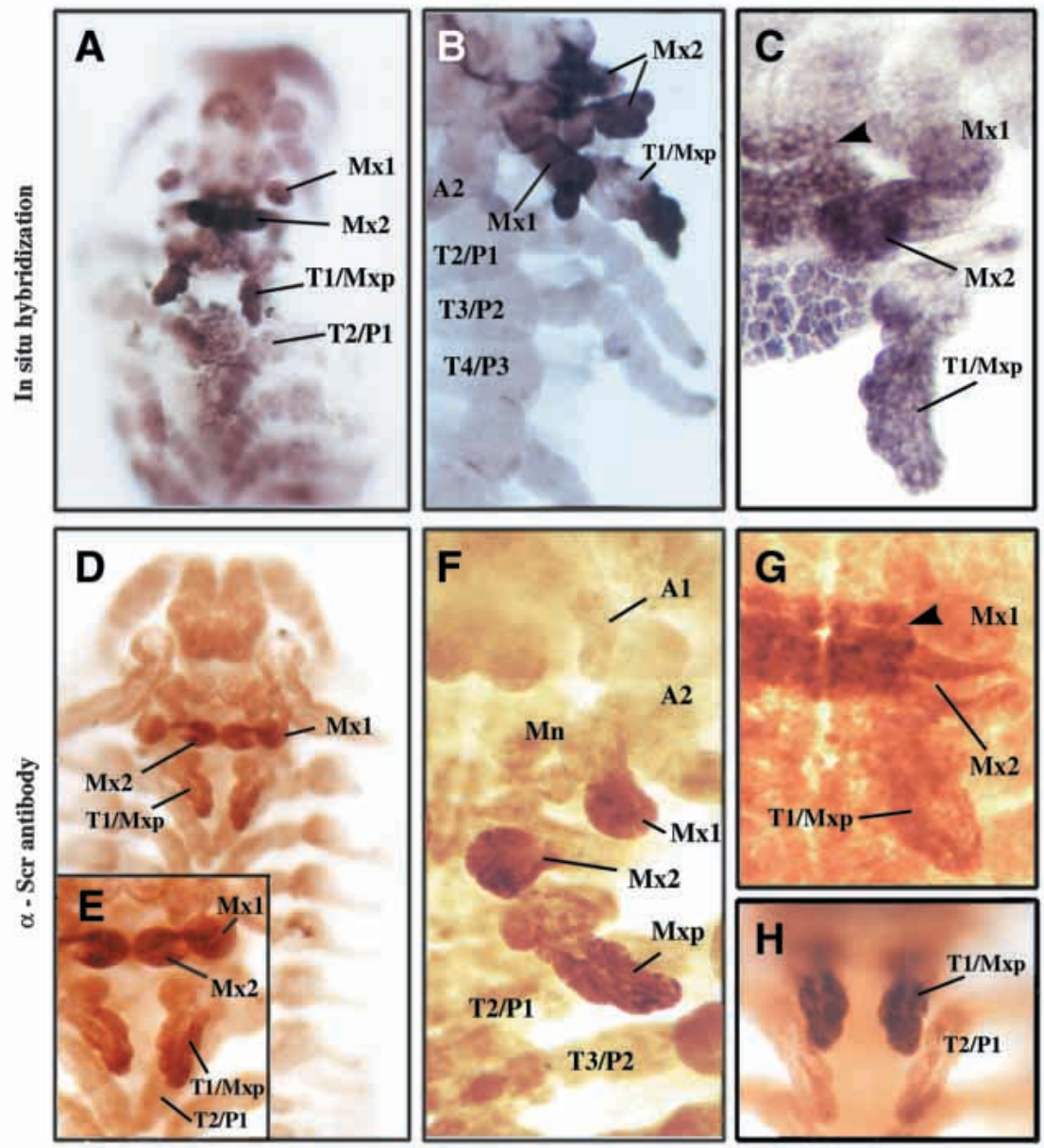

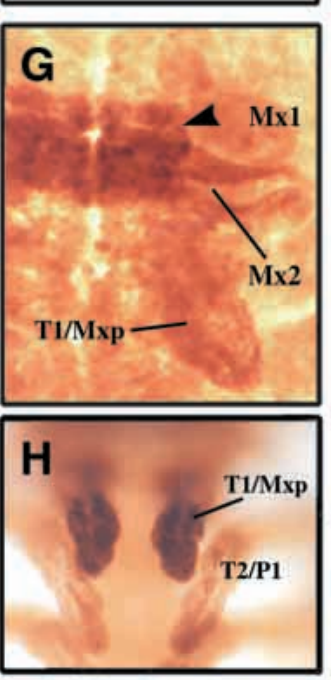

Fig. 5. Similar pattern in localization of Scr mRNA and protein in $75-80 \%$ stage embryos. All labels as in Fig. 2. (A) Scr continues to be expressed at high levels in the Mx1, Mx2 and Mxp appendages and the ventral ectoderm of the Mx2 segment.

(B) Higher magnification of the head of a similar embryo. Scr is expressed in the appendages of the posterior head but not in the pereopod legs. The T4/P3 leg was lost during processing. (C) This image focuses on the ventral ectoderm of the Mx1 and Mx2 segments rather then appendages. $\mathrm{Scr}$ mRNA is seen in 3-4 rows of cells in the posterior part of the ventral ectoderm of the Mx1 segment and outer branch of the first maxillae, all of the Mx2 segment including second maxillae and most of the flat maxilliped. There is non-specific cuticular staining on the ventral ectoderm of the segment bearing the Mxp appendages. (D) In late embryos $\mathrm{SCR}$ is present in the Mx1, Mx2, maxilliped limbs and in the Mx2 ventral ectoderm (as detected with the polyclonal antibody against SCR). (E) Higher magnification of the same embryo. (F) Antibody staining of an embryo at the same stage as D. Most of the head and anterior thorax is shown. SCR is not detected in T2/P1 or other pereopods, but high levels are seen in the Mxp. (G) SCR is detected in the posterior part of the Mx1 segment and in the first maxillae, throughout $\mathrm{Mx} 2$ segment and appendages, and in the maxillipeds. This pattern is identical to C. The appendages of this embryo are out of focus but animals at this stage display very high levels of SCR in the maxillipeds $(\mathrm{H})$. intermediate metamorphoses, and in many crustacean taxa a similar transformation of one or more pairs of the anterior thoracic appendages into maxillipeds occurs at various larval stages as a part of metamorphosis (Kaestner, 1970). We suggest that the post-transcriptional regulation of $\mathrm{Scr}$ during $P$. scaber embryogenesis may reflect a possible mechanism through which these swift and drastic changes can take place. The exact timing in appearance of high levels of SCR may be important in activation of distinctive developmental programs in maxilliped morphogenesis. For example, the homeotic functions of $U b x$ and Antp depend on timing and dosage of expression in Drosophila development (Castelli-Gair et al., 1994; Scanga et al., 1995). Although post-transcriptional regulation has been reported for the vertebrate Hoxc- 6 gene (Nelson et al., 1996) and other developmental genes (Dubnau and Struhl, 1996), it is a novel mode of regulation for HOM$\mathrm{C} / \mathrm{Hox}$ genes in arthropods. We should note that a delay in protein appearance has been previously reported for the Drosophila homeotic genes labial, Scr, Antp and Ubx, and posttranscriptional controls have been suggested (Mahaffey and Kaufman, 1987; Riley et al., 1987; Wilde and Akam, 1987). It is possible that a homologous and widespread molecular mechanism is at work in arthropods as distant as isopods and dipterans. However, the apparent post-transcriptional regulation of Scr in Drosophila and of Hoxc-6 in chick limbs (Nelson et al., 1996) is not associated with the obvious alteration in morphogenesis seen in the case of the T1 leg to maxilliped transformation documented here. The exact mechanism for post-transcriptional regulation of $S \mathrm{cr}$ remains unclear but might involve control via regulatory sequences within untranslated regions of the mRNA (Chan and Struhl, 1997; Wilde and Akam, 1987). A detailed genetic and molecular analysis of this kind of regulation in Drosophila and other 'model' organisms would be helpful in determining the possible mechanism(s). Minimally, the observations reported here should serve as a caveat indicating that we should not derive too far-reaching phylogenetic conclusions based on patterns of gene expression obtained solely from the accumulation of mRNA.

Despite the lack of genetic tools, the studies on HOM-C/Hox genes in non-insect arthropods are important as they may provide some insights into mechanisms of evolution that are otherwise impossible to attain. The representatives of the four extant classes of arthropods are among the most successful and diverse animals on the planet. As the fossil record shows, the morphological diversity on the basic level was even greater in the past when many groups of arthropods, most of them now extinct, displayed truly phenomenal combinations of morphological features. Crustaceans demonstrate extensive modifications of their basic body plan including independent tagmatization and numerous specializations of body segments and appendages, more so than any other group of animals (Schram, 1986). It is tempting to hypothesize that post- 
transcriptional regulation of Hox genes, if widespread, could account for some of this diversity.

We thank R. Turner for the SEM, M. Peterson for providing primers and protocols, Thierry Rigaud for identifying woodlouse species, R. White for FP6.87 antibody, G. Panganiban for DLL antibody, D. J. Andrew for SCR antibody, N. Patel for EN/INV antibody, and S. Glueck, K. Matthews, D. Rusch, M. Peterson and T. Powers for helpful comments on the manuscript. This work was supported by the HHMI. T. C. K. is an investigator of the Howard Hughes Medical Institute (HHMI).

\section{REFERENCES}

Arnone, M. I. and Davidson, E. H. (1997). The hardwiring of development: Organization and function of genomic regulatory systems. Development 124, 1851-1864.

Averof, M. and Akam, M. (1995). Hox genes and the diversification of insect and crustacean body plans. Nature 376, 420-423.

Averof, M. and Patel, N. H. (1997). Crustacean appendage evolution associated with changes in Hox gene expression. Nature 388, 607-698.

Ballard, J. W., Olsen, G. J., Faith, D. P., Odgers, W. A., Rowell. D. M. and Atkinson, P. W. (1992). Evidence from 12S ribosomal RNA sequences that onychophorans are modified arthropods. Science 258, 1345-1348.

Beeman, R. W., Stuart, J. J., Brown, S. J. and Denell, R. E. (1993). Structure and function of the homeotic gene complex (HOM-C) in the beetle, Tribolium castaneum. BioEssays 15, 439-444.

Beklemishev, W. N. (1964). Principles of the Comparative Anatomy of Invertebrates. The University of Chicago Press, Chicago.

Boore, J. L., Collins, T. M., Stanton, D., Daehler, L. L. and Brown, W. M. (1995). Deducing the pattern of arthropod phylogeny from mitochondrial DNA rearrangements. Nature 376, 163-165.

Boore, J. L., Lavrov, D. V. and Brown, W. M. (1998). Gene translocation links insects and crustaceans. Nature 392, 667-668.

Brusca, R. C. and Brusca, G. J. (1990). Invertebrates. Sinauer Associates Inc., Sunderland, Massachusetts.

Carroll, S. B. Dinardo, S., O'Farrell, P., White, R. and Scott, M. (1988). Temporal and spatial relationships between segment segmentation and homeotic gene expression in Drosophila embryos: distribution of the fushi tarazu, engrailed, Sex combs reduced, Antennapedia and Ultrabithorax proteins. Genes Dev. 2, 350-360.

Carroll, S. B. (1994). Developmental regulatory mechanisms in the evolution of insect diversity. Development Supplement, 217-223.

Carroll, S. B. (1995). Homeotic genes and the evolution of arthropods and chordates. Nature 376, 479-485.

Castelli-Gair, J., Greig, S., Micklem, G. and Akam, M. (1994). Dissecting the temporal requirements for homeotic gene function. Development 120, 1983-1995.

Cavener, D. C. (1992). Transgenic animal studies on the evolution of genetic regulatory circuitries. BioEssays 14, 237-244.

Chan, S. K. and Struhl, G. (1997). Sequence-specific RNA binding by Bicoid. Nature 388, 634.

Dubnau, J. and Struhl, G. (1996). RNA recognition and translational regulation by a homeodomain protein. Nature 379, 694-699.

Friedrich, M. and Tautz, D. (1995). Ribosomal DNA phylogeny of the major extant arthropod classes and the evolution of myriapods. Nature 376, 165167.

Gellon, G. and McGinnis, W. (1998). Shaping animal body plans in development and evolution by modulation of Hox expression patterns. BioEssays 20, 116-125.

Gilbert, S. F. and Raunio, A. M. (1997). Embryology: Constructing the Organism. Sinauer Associates Inc., Sunderland, Massachusetts.

Gorman, M. J. and Kaufman, T. C. (1995). Genetic analysis of cis-acting regulatory elements of the Drosophila homeotic gene Sex combs reduced. Genetics 140, 557-572.

Graba, Y., Aragnol, D. and Pradel, J. (1997). Drosophila Hox complex downstream targets and the function of homeotic genes. BioEssays 19, 379388.

Kaestner, A. (1970). Invertebrate Zoology, Vol. III. Interscience Publishers, New York.

Kaufman, T. C., Seeger, M. A. and Olsen, G. (1990). Molecular and genetic organization of the Antennapedia gene complex of Drosophila melanogaster. Adv. Genet. 27, 309-362.

Kelsh, R., Weinzierl, R. O. J., White, R. A. H. and Akam, M. (1994). Homeotic gene expression in the locust Schistocerca: an antibody that detects conserved epitopes in Ultrabithorax and Abdominal-A proteins. Dev. Genet. 15, 19-31.

Lawrence, P. and Morata, G. (1994). Homeobox genes: their function in Drosophila segmentation and pattern formation. Cell 78, 181-189.

Li, X. and Noll, M. (1994). Evolution of distinct developmental functions of three Drosophila genes by acquisition of different cis-regulatory regions. Nature 367, 83-86.

Mahaffey, J. W. and Kaufman, T. C. (1987). Distribution of the Sex combs reduced gene products in Drosophila melanogaster. Genetics 117, 51-60.

Manton, S. M. (1977). The Arthropoda. Habits, Functional Morphology and Evolution. Oxford University, Oxford.

Manzanares, M., Marco, R. and Garesse, R. (1993). Genomic organization and developmental pattern of the engrailed gene from the brine shrimp Artemia. Development 118, 1209-1219.

McGinnis, W. and Krumlauf, R. (1992). Homeobox genes and axial patterning. Cell 68, 283-302.

Nelson, C. E., Morgan, B. A., Burke, A. C., Laufer, E., DiMambro, E., Murtaugh, L. C., Gonsales, E., Tessarollo, L., Parada, L. F. and Tabin, C. (1996). Analysis of Hox gene expression in the chick limb bud. Development 122, 1449-1466.

Osorio, D., Averof, M. and Bacon, J. P. (1995). Arthropod evolution: great brains, beautiful bodies. Trends Ecol. Evol. 10, 449-454.

Panganiban, G., Nagy, L. and Carroll, S. (1994). The role of Distal-les gene in the development and evolution of insect limbs. Curr. Biol. 4, 671-675.

Patel, N. H., Martin-Blanco, E., Coleman, K. G., Poole, S. J., Ellis, M. C., Kornberg, T. B. and Goodman, C. S. (1989a). Expression of engrailed proteins in arthropods, annelids and chordates. Cell 58, 955-968.

Patel, N. H., Kornberg, T. B. and Goodman, C. S. (1989b). Expression of engrailed during segmentation in grasshopper and crayfish. Development 107, 201-212.

Pattatucci, A. and Kaufman, T. C. (1991). The homeotic gene Sex combs reduced is differentially regulated in the embryonic and imaginal stages of development. Genetics 129, 443-461.

Peterson, M. D., Rogers, B. T., Popadic, A. and Kaufman, T. C. (1998). The embryonic expression pattern of labial, posterior homeotic complex genes and the teashirt homologue in an apterygote insect. Dev. Genes Evol. (in press)

Popadic, A., Abzhanov, A., Rousch, D. and Kaufman, T. C. (1998). Understanding the genetic basis of morphological evolution: the role of homeotic genes in the diversification of the arthropod bauplan. Int. J. Dev. Biol. 42, 453-461.

Rogers, B. T. and Kaufman, T. C. (1996). Structure of the insect head as revealed by the EN protein pattern in developing embryos. Development 122, 3419-3432.

Rogers, B. T. and Kaufman, T. C. (1997). Structure of the insect head in ontogeny and phylogeny: a view from Drosophila. Int. Rev. Cytol. 174, 1-84.

Rogers, B. T., Peterson, M. D. and Kaufman, T. C. (1997). Evolution of the insect body plan as revealed by the Sex combs reduced expression pattern. Development 124, 149-157.

Riley, P. D., Carroll, S. B. and Scott, M. P. (1987). The expression and regulation of Sex combs reduced protein in Drosophila embryos. Genes Dev. 1, 716-730.

Scanga, S., Manoukian, A. and Larsen. E. (1995). Time- and concentration dependent response of the Drosophila antenna imaginal disc to Antennapedia. Dev. Biol. 169, 673-682.

Schram, F. R. (1986). Crustacea. Oxford University Press, Inc., New York.

Warren, R. W., Nagy, L., Selegue, J., Gates, J. and Carroll, S. (1994). Evolution of homeotic gene regulation and function in flies and butterflies. Nature 372, 458-461.

Warren, R. and Carroll, S. B. (1995). Homeotic genes and diversification of the insect body plan. Curr. Opin. Genet. Dev. 5, 459-465.

Whitington, P. M., Leach, D. and Sandeman, R. (1993). Evolutionary change in neural development within arthropods: axogenesis in the embryos of two crustaceans. Development 118, 449-461.

Wilde, C. D. and Akam, M. (1987). Conserved sequence elements in the 5' region of the Ultrabithorax transcription unit. EMBO J. 6, 1393-1401.

Zeng, W. Andrew, D. J., Mathies, L. D., Horner, M. A. and Scott, M. P. (1993). Ectopic expression and function of Antp and Scr homeotic genes: the $\mathrm{N}$ terminus of the homeodomain is critical to functional specificity. Development 118, 339-352. 